\title{
Relationships of Adrenoceptor Polymorphisms with Obesity
}

\author{
Kazuko Masuo ${ }^{1,2}$ and Gavin W. Lambert ${ }^{2}$ \\ ${ }^{1}$ Nucleus Network, Ltd, Baker IDI Heart and Diabetes Research Institute, 89 Commercial Road, Melbourne, VIC 3004, Australia \\ ${ }^{2}$ Human Neurotransmitter Laboratory, Baker IDI Heart and Diabetes Research Institute, Melbourne, VIC 3004, Australia
}

Correspondence should be addressed to Kazuko Masuo, kazuko.masuo@bakeridi.edu.au

Received 24 November 2010; Accepted 7 February 2011

Academic Editor: Eric Doucet

Copyright ( $\odot 2011$ K. Masuo and G. W. Lambert. This is an open access article distributed under the Creative Commons Attribution License, which permits unrestricted use, distribution, and reproduction in any medium, provided the original work is properly cited.

Obesity, hypertension, and type 2 diabetes are rapidly growing public health problems. Heightened sympathetic nerve activity is a well-established observation in obesity, hypertension, and type 2 diabetes. Human obesity, hypertension, and diabetes have strong genetic as well as environmental determinants. Reduced energy expenditure and resting metabolic rate are predictive of weight gain, and the sympathetic nervous system participates in regulating energy balance through thermogenesis. The thermogenic effects of catecholamines in obesity are mainly mediated via the $\beta 2$, and $\beta 3$-adrenergic receptors in humans. Further, $\beta 2$ adrenoceptors importantly influence vascular reactivity and may regulate blood pressure. $\beta$-adrenoceptor polymorphisms have also been associated with adrenoceptor desensitization, increased adiposity, insulin resistance, and enhanced sympathetic nervous activity. Many epidemiological studies have shown strong relationships between adrenoceptor polymorphisms and obesity, but the observations have been discordant. This paper will discuss the current topics involving the influence of the sympathetic nervous system and $\beta 2$ - and $\beta 3$-adrenoceptor polymorphisms in obesity.

\section{Introduction}

Obesity is a major and growing health problem. Importantly, the presence of increased adiposity is associated with elevated risk of development of cardiovascular and renal complications [1-4]. Obesity is frequently associated with hypertension, diabetes, and metabolic syndrome [5-7], and sympathetic nervous activation is frequently observed in those conditions [8]. Thus, sympathetic nerve activation may play a major role in the onset and development of obesity, hypertension, and the development of the metabolic syndrome as well as controlling to the cardiovascular complications evident in patients with hypertension, diabetes, and obesity $[2,4,9]$.

The sympathetic nervous system plays an important role in the regulation of energy expenditure. Reduced energy expenditure and resting metabolic rate are predictive of weight gain (obesity). Furthermore, blunted sympathetic nervous responses to energy intake have been observed in obese subjects with the metabolic syndrome and insulin resistance $[10,11]$. The sympathetic nervous system participates in regulating energy balance through thermogen- esis [12]. Recently, the important relationships of brown adipose tissue for energy expenditure [13-15] were argued, however a large part of the sympathetic nervous systemmediated energy expenditure takes place in skeletal muscle, via the coupling of catecholamines with $\beta 2$-adrenoceptors. Catecholamines are also powerful regulators of lipolysis and act via $\beta 1$-, $\beta 2$-, $\beta 3$-(stimulatory), and $\alpha 2$-(inhibitory) adrenoceptor subtypes in adipose tissue, where their role becomes especially important during both exercise and energy restriction, when increased need for fat as a fuel exists. Thus, $\beta$-adrenoceptors play important roles in energy expenditure and control body weight [16-20].

Recent evidence indicates that human obesity indeed has a genetic component with [21-23] several epidemiological and clinical studies indicating a strong linkage between $\beta$ adrenoceptor polymorphisms and obesity or weight gain $[24,25]$. Furthermore, heightened sympathetic nervous system activity associated with $\beta 2$ - and $\beta 3$-adrenoceptor polymorphisms predicts subsequent weight gain and blood pressure elevation in originally nonobese subjects [11, 24], and rebound weight gain after significant weight loss in obese subjects [26]. $\beta 2$-adrenoceptor polymorphisms are related to 
the onset of insulin resistance [27] and blunted responses of sympathetic nerve activity to acute hyperinsulinemia $[10,11$, 27-29]. These findings show that the genetic background, especially $\beta 2$ - and $\beta 3$-adrenoceptor polymorphisms, are associated with sympathetic nervous system activation, and are important in the pathogenesis of obesity-related hypertension and insulin resistance. Many investigations regarding the relationships between $\beta$-adrenoceptor polymorphisms and obesity have been analysed; however, the results are discordant [30-32].

\section{Role of the Sympathetic Nervous System in Obesity}

Many epidemiological and clinical studies have demonstrated a close relationship between sympathetic nervous activation and insulin levels in obesity [33-37]. Several longitudinal studies have examined the effect of body weight changes (weight loss or weight gain) on sympathetic nervous system activity and insulin sensitivity (fasting plasma insulin levels and HOMA-IR). Elevated activity of the sympathetic nervous system and increased insulin levels during weight gain $[16,24,26,38,39]$ and reductions of sympathetic nerve activity and insulin levels during weight loss [4045] have been observed. In obese normotensive subjects, a reduction in body weight induced exerts a marked reduction in sympathetic activity owing to central sympathoinhibition due to the consequences of an increased insulin sensitivity and a restoration of the baroreflex [45]. These studies have clearly shown heightened sympathetic nerve activity and insulin resistance are closely linked to weight gain and the onset and maintenance of obesity.

Landsberg et al. [46-48] and Julius et al. [49] have proposed hypotheses to explain the mechanism linking the sympathetic nervous system and insulin resistance in obesity. The former proposes that hyperinsulinemia and insulin resistance in obese subjects are all part of a response to limit further weight gain via stimulating sympathetic nervous activity and thermogenesis [50], and the latter indicates that sympathoexcitation in the skeletal muscle vascular bed cause neurogenic vasoconstriction and reduction in blood flow to muscle and consequently induces a state of insulin resistance by lowering glucose delivery and uptake in hypertension and obesity. Masuo et al. in a series of longitudinal studies observed that heightened sympathetic activity was the prime mover for future weight gain in originally nonobese, normotensive subjects, and that insulin resistance was more an ancillary factor $[24,51,52]$. In investigations examining the effect of weight loss, reductions in plasma norepinephrine followed by reductions in HOMA-IR as a marker of insulin resistance were significantly greater in subjects experiencing significant weight loss compared to those without significant weight loss [26, 40, 43]. These observations provide some support for the hypothesis of Julius and colleagues.

Valentini et al. [53] reported attenuation of hemodynamic and energy expenditure responses to isoproterenol infusion in hypertensive patients. Their findings that a generalized decrease of $\beta$-adrenergic responsiveness in hyper- tension supports the hypothesis that heightened sympathetic nerve activity, through downregulation of $\beta$-adrenoceptormediated thermogenesis, may facilitate the development of obesity in hypertension. Their results suggested that sympathetic nerve activity-induced hypertension may subsequently lead to the development of obesity.

\section{Role of $\beta$-Adrenoceptor Polymorphisms in Obesity}

The sympathetic nervous system plays an important role in the regulation of energy expenditure. A large part of the sympathetic nervous system-mediated energy expenditure takes place in skeletal muscle, via the coupling of catecholamines with $\beta 2$-adrenoceptors [54]. Catecholamines are also powerful regulators of lipolysis and act via $\beta 1-, \beta 2-, \beta 3-$ (stimulatory) and $\alpha 2$-(inhibitory) adrenoceptor subtypes in adipose tissue, where their role becomes especially important during both exercise and energy restriction, when increased need for fat as a fuel exists. Stimulation of $\beta$-adrenergic receptors by the sympathetic nervous system is a significant physiological modulator of pre- and postprandial energy expenditure [18-20] and total daily energy expenditure $[16,17,50]$. The subtypes of adrenoceptors on lipid and glucose metabolisms are summarized as following; $\alpha 1$-adrenoceptors, glycogenolysis and gluconeogenesis in adipose tissue and liver; $\alpha 2$-adrenoceptors, induction of glucagon release from pancreas; $\beta 1$-adrenoceptors, lipolysis in adipose tissue; $\beta 2$-adrenoceptors, glycogenolysis and gluconeogenesis in adipose tissue and liver; $\beta 3$-adrenoceptors, lipolysis on adipose tissue.

Recent studies show that $\beta$-adrenoceptors are polymorphic with single nucleotide polymorphisms exerting functional consequences in terms of receptor activity and regulation and hence perhaps may contributing to the pathophysiology of obesity and hypertension [24, 25, 55-59]. On the other hand, there are few studies on the relationships between $\alpha$-adrenoceptor polymorphisms and obesity.

3.1. $\beta 1$-Adrenoceptor Polymorphisms (Table 1). The $\beta 1$ adrenoceptor is predominantly expressed in cardiac myocytes and adipose tissue, where its activation leads to increased heart rate and contractility and stimulation of lipolysis, respectively. The $\beta 1$-adrenoceptor is a candidate gene for obesity because of its role in catecholaminemediated energy homeostasis. In obese individuals, the degree of weight loss during a very low calorie diet has been shown to correlate with changes in $\beta 1$-adrenoceptor protein concentration in adipose tissue [65]. The two most common $\beta 1$-adrenoceptor polymorphisms are Ser49Gly and Arg389Gly, with relative allele frequencies of $0.85 / 0.15$ and $0.70 / 0.30$ in Caucasian population, respectively. An investigation involving a population cohort of 761 women indicated that women carrying the Gly49 genotype had greater elevation in BMI over 15 years compared to those with the Ser49 genotype [62]. Again, in Caucasian women ( $n=931$ ), Dionne et al. [60] observed that the Gly389Arg, $\beta 1$-adrenoceptor variant exhibited a strong relationships 
TABLE 1: Summary of studies showing associations between on $\beta 1$-adrenoceptor polymorphisms and obesity.

\begin{tabular}{|c|c|c|c|c|}
\hline $\begin{array}{l}\text { Authors } \\
\text { (reference) }\end{array}$ & Year & Population & Subjects & Findings \\
\hline Dionne et al. [60] & 2002 & Caucasian & 931 women & $\begin{array}{l}\text { Arg allele of Argt } 389 \text { Gly was associated with obesity (greater body weight } \\
\text { and BMI due to greater fat mass). }\end{array}$ \\
\hline Tafel et al. [61] & 2004 & German & $\begin{array}{l}\text { Children and } \\
\text { adolescents }\end{array}$ & $\begin{array}{l}\text { The distributions of Ser49Gly and Arg389Gly were not different between } \\
\text { lean and obese adolescents. }\end{array}$ \\
\hline Linné et al. [62] & 2005 & Scandinavian & 761 women & $\begin{array}{l}\text { The combination of Gly49-Gly389 (Ser49Gly + Arg389Gly) was associated } \\
\text { with long term of } 15 \text { years weight gain and the incidence of adult-onset } \\
\text { overweight in women, but no effect of Arg389Gly alone on obesity. }\end{array}$ \\
\hline Gjesing et al. [63] & 2007 & $\begin{array}{l}\text { Danish- } \\
\text { Caucasians }\end{array}$ & 7,677 & $\begin{array}{l}\text { Arg389Gly polymorphism was not related with obesity, but minor influence } \\
\text { on BP. }\end{array}$ \\
\hline Nonen et al. [64] & 2008 & Japanese & $\begin{array}{l}188 \text { type } 2 \\
\text { diabetic } \\
\text { patients }\end{array}$ & Ser49Gly, but not Arg389Gly, was associated with obesity. \\
\hline
\end{tabular}

BP: blood pressure.

with obesity. Conversely, Gjesing and colleagues found that the distribution of the Arg389Gly polymorphism was similar in lean and obese subjects, suggesting that it has no important influence on human obesity $[63,66]$. Although earlier small case-control studies demonstrated an increase in the risk of hypertension in Arg389 homozygotes [67, 68], a recently published study comprising 3981 normotensive and 2,518 hypertensive patients failed to replicate this association [63] (summarised in Table 1). Arner [67] reviewed that Arg389Gly polymorphism in the $\beta 1$-adrenoceptor, which alters receptor function in transfected cell lines, and concluded that the SNP has no effect on lipolysis in human fat cells and is not associated with obesity.

3.2. $\beta 2$-Adrenoceptor Polymorphisms (Table 2). The $\beta 2$ adrenoceptor is the dominant lipolytic receptor in white human adipose tissue $[20,55,56]$ and in skeletal muscle $[19,57]$. Gln16Glu and an Arg164Ile variation in the $\beta 2$-adrenoceptor cause marked variations in the lipolytic sensitivity of this receptor in human adipocytes. Multiple $\beta 2$-adrenoceptor polymorphisms including haplotypes, markedly influence $\beta 2$-receptor function- and catecholamine-induced lipolysis in fat cells [76]. These haplotypes may be important genetic factors behind impaired lipolysis in obesity [25].

The $\beta 2$-adrenoceptor also plays an important regulatory role in the peripheral vasculature. Genetic polymorphisms of the $\beta 2$-adrenoceptor have been associated with obesity, hypertension, and diabetes mellitus. The most common polymorphisms are Arg16Gly, with an allele frequency of $0.40 / 0.60$ and Gln27Glu, with an allele frequency of $0.55 / 0.45$ in the Caucasian population. The Thr164Ile polymorphism is rare, occurring in only 3 to $5 \%$ of the general (Caucasian) population.

Studies of agonist stimulation in cultured cells demonstrate that Gly16 receptors have a greater reduction in numbers or enhanced downregulation when compared with
Arg16, whereas the Glu27 receptor is resistant to down regulation when compared with the Gln27 variant [77]. A number of clinical studies have investigated the impact of these polymorphisms on vascular responsiveness [55, 78]. Gratze et al. [79] found that young normotensive white men homozygous for the Gly16 allele had higher blood pressure and lower peripheral vasodilation after infusion of the $\beta 2$ agonist salbutamol. Similar results were obtained by Hoit et al. [80] using the agonist terbutaline. On the other hand, volunteers homozygous for Gly16 exhibited larger vasodilatory responses than did volunteers homozygous for Arg16 [81]. Conflicting results have also been published with regards to the effects of genetic variants on the sympathetic nervous system modulation of energy expenditure. Bell et al. [82] reported that the response of resting energy expenditure to nonspecific $\beta$-adrenoceptor stimulation (with isoproterenol infusion) was not different between the 3 genotypes of Arg16Gly. Stob et al. [70] showed that individuals carrying the Arg16Arg variant of the $\beta 2$-adrenoceptor gene have a reduced thermogenic response to selective $\beta 2$-adrenoceptor activation.

Associations of $\beta 2$-adrenoceptor polymorphisms with obesity have been reported in many epidemiological studies but results are also discordant (summarised in Table 2).

3.3. B3-Adrenoceptor Polymorphisms (Table 3). The $\beta 3$ adrenoceptor, which is mainly expressed in adipose tissue, differs from the $\beta 2$-adrenoceptor in two ways: it has a lower affinity for catecholamines, and it resists desensitisation (i.e., downregulation). These characteristic differences might lead to the different effects of catecholamine on $\beta 2$-adrenoceptors and $\beta 3$-adrenoceptors. $\beta 3$-adrenoceptors stimulates the mobilization of lipids from the white adipose tissue and increases thermogenesis in brown adipose tissue. Cypess et al. and other investigators demonstrated that potential roles of $\beta 3$-adrenoceptor polymorphism (Trp64Arg) associated with potential role of uncoupling protein (UCP) 
TABLE 2: Summary of studies showing associations between $\beta 2$-adrenoceptor polymorphisms and obesity.

\begin{tabular}{|c|c|c|c|c|}
\hline Authors [reference] & Year & Population & Subjects & Findings \\
\hline Large et al. [55] & 1997 & Swedish & $\begin{array}{l}\text { Caucasian women with } \\
\text { wide range of obesity }\end{array}$ & Gln27Glu polymorphism was associated with obesity. \\
\hline Echwald et al. [58] & 1998 & Danes & $\begin{array}{l}\text { Caucasian juvenile-onset } \\
\text { obese men }\end{array}$ & No association between Gln27Glu and obesity. \\
\hline Hellström et al. [59] & 1999 & Swedish & $\begin{array}{l}\text { Swedish-Caucasian men } \\
\text { and women }\end{array}$ & $\begin{array}{l}\text { Gln27Glu polymorphism was associated with obesity only in } \\
\text { women, but not in men. }\end{array}$ \\
\hline Kortner et al. [69] & 1999 & German & $\begin{array}{l}\text { Caucasian with morbid } \\
\text { obesity }\end{array}$ & Gln27Glu polymorphism was not associated with obesity. \\
\hline $\begin{array}{l}\text { The Quebec Family } \\
\text { Study [70] }\end{array}$ & 2000 & Canadian & $\begin{array}{l}\text { Caucasian men and } \\
\text { women }\end{array}$ & $\begin{array}{l}\text { Gln27Glu polymorphism was associated with obesity and } \\
\text { hyperlipidemia. }\end{array}$ \\
\hline Ukkola et al. [56] & 2001 & USA & $\begin{array}{l}12 \text { pairs of twins, } \\
\text { Caucasians }\end{array}$ & $\begin{array}{l}\text { Gln } 27 \text { Glu polymorphism was associated with weight gain } \\
\text { (obesity). }\end{array}$ \\
\hline $\begin{array}{l}\text { Meirhaeghe et al. } \\
\text { [71] }\end{array}$ & 2000 & French & 1,195 subjects & $\begin{array}{l}\text { Subjects carrying Gln } 27 \text { homozygous had an increased risk of } \\
\text { obesity in men, but not in women. Further, men with Gln } 27 \\
\text { homozygous carried in addition the Arg } 16 \text { allele, had more } \\
\text { significant increase in body weight, BMI and waist-to-hip ratio } \\
\text { (central obesity). }\end{array}$ \\
\hline $\begin{array}{l}\text { The HERITAGE } \\
\text { family study [72] }\end{array}$ & 2003 & Canada & $\begin{array}{l}\text { Sedentary black and } \\
\text { white men }\end{array}$ & $\begin{array}{l}\text { Gln } 27 \text { Glu polymorphism was associated with lower fat in obese } \\
\text { white men. }\end{array}$ \\
\hline Pereira et al. [25] & 2003 & Brazilian & $\begin{array}{l}1,576 \text { individuals } \\
\text { randomly selected }\end{array}$ & $\begin{array}{l}\text { Subjects carrying Gln } 27 \text { homozygous had higher risk of obesity, } \\
\text { whereas those with Gly } 27 \text { homozygous had increased risk of } \\
\text { hypertension. }\end{array}$ \\
\hline Jiao et al. [73] & 2005 & Scandinavian & $\begin{array}{l}1,354 \text { women and } 421 \\
\text { men }\end{array}$ & $\begin{array}{l}\text { Common haplotypes of ADRB2 polymorphisms had recessive } \\
\text { effects against excess body fat only in women, but not in men. }\end{array}$ \\
\hline Masuo et al. [26] & 2005 & Japanese & $\begin{array}{l}154 \text { overweight/obese } \\
\text { men }\end{array}$ & $\begin{array}{l}\text { Gly16 allele was related to obesity and rebound weight gain in } \\
\text { weight-loss study. }\end{array}$ \\
\hline Masuo et al. $[24,27]$ & 2005 & Japanese & $\begin{array}{l}160 \text { nonobese, } \\
\text { normotensive men }\end{array}$ & $\begin{array}{l}\text { Gly16 allele was related to future weight gain, BP elevation and } \\
\text { insulin resistance in originally nonobese, normotensive men. }\end{array}$ \\
\hline Masuo et al. [28] & 2006 & Japanese & $\begin{array}{l}329 \text { normotensive men } \\
\text { with a wide range of } \\
\text { BMI }\end{array}$ & $\begin{array}{l}\text { Gly16 and Glu27 alleles were related to obesity through } \\
\text { blunted-leptin-mediated sympathetic activity. }\end{array}$ \\
\hline $\begin{array}{l}\text { Kawaguchi et al. } \\
\text { [29] }\end{array}$ & 2006 & Japanese & $\begin{array}{l}55 \text { overweight/obese } \\
\text { men }\end{array}$ & Gly16 allele was related to further weight gain in obese subjects. \\
\hline Petrone et al. [74] & 2006 & European & $\begin{array}{l}642 \text { overweight/obese } \\
\text { subjects }\end{array}$ & $\begin{array}{l}\text { The haplotype of } 5^{\prime} \mathrm{LC}-\mathrm{Cys}(19) \operatorname{Arg}(16) \mathrm{Gln}(27) \text { was related to } \\
\text { additional weight gain with increases of triglycerides and } \\
\text { LDL-cholesterol. }\end{array}$ \\
\hline Gjesing et al. [75] & 2009 & Danes & 6,514 adults & $\begin{array}{l}\text { No consistent effect of ADRB2 haplotypes on obesity and } \\
\text { quantitative traits of body fatness. }\end{array}$ \\
\hline
\end{tabular}

ADRB2: $\beta 2$-adrenoceptors; BP: blood pressure.

polymorphisms and brown adipose tissue in thermogenesis and resultant body weight in humans [13-15]. Decreased function of $\beta 3$-adrenoceptor in white adipose tissue could slow lipolysis and thereby cause the retention of lipids in adipocytes. Slow lipolysis may contribute strongly to visceral obesity in human, and treatment of obese animal models with selective $\beta 3$-adrenergic agonists reduces fat stores effectively [88-90]. Hoffstedt et al. [91] compared adrenergic regulation of lipolysis between omental and subcutaneous adipocytes from 15 obese and 14 nonobese men. In their study, catecholamine-induced lipolysis was markedly increased in omental adipocytes as compared to subcutaneous adipocytes in obese male subjects mainly due to an increase in $\beta 3$-adrenoceptor function of visceral fat, 
TABLE 3: Summary of studies showing associations between $\beta 3$-adrenoceptor polymorphisms and obesity.

\begin{tabular}{|c|c|c|c|c|}
\hline Authors [reference] & Year & Population & Subjects & Findings \\
\hline Clement et al. [83] & 1995 & French & $\begin{array}{l}\text { Patients with morbid } \\
\text { obesity }\end{array}$ & $\begin{array}{l}\text { Subjects carrying } \beta 3 \text {-ADR polymorphisms has an increased } \\
\text { capacity to gain weight. }\end{array}$ \\
\hline Sakane et al. [84] & 1997 & Japanese & $\begin{array}{l}61 \text { obese women with } \\
\text { type } 2 \text { diabetes }\end{array}$ & $\begin{array}{l}\text { The Arg64 allele of Trp64Arg may predict difficulty in losing body } \\
\text { weight, lowering waist-to-hip ratio, and improving glycemic } \\
\text { control and insulin resistance in obese patients with type } 2 \\
\text { diabetes. }\end{array}$ \\
\hline Umekawa et al. [85] & 1999 & Japanese & $\begin{array}{l}18 \text { omental fat samples } \\
\text { obtained during total } \\
\text { hysterectomy }\end{array}$ & $\begin{array}{l}\text { Trp64Arg polymorphism was associated with lower lipolytic } \\
\text { activities. }\end{array}$ \\
\hline Endo et al. [86] & 2000 & Japanese & $\begin{array}{l}553 \text { Japanese } \\
\text { schoolchildren ( } 291 \text { boys } \\
\text { and } 262 \text { girls) }\end{array}$ & $\begin{array}{l}\text { Trp64Arg polymorphism might be a genetic risk factor for obesity } \\
\text { in Japanese children. }\end{array}$ \\
\hline Oizumi et al. [87] & 2001 & Japanese & $\begin{array}{l}1,685 \text { (935 women and } \\
750 \text { men) }\end{array}$ & $\begin{array}{l}\text { Arg64/Arg64, but not Trp64/Arg64, of the } \beta \text {-adrenergic receptor } \\
\text { polymorphism was associated with both obesity and type } 2 \\
\text { diabetes in a large Japanese cohort. }\end{array}$ \\
\hline Masuo et al. [24] & 2005 & Japanese & $\begin{array}{l}160 \text { nonobese, } \\
\text { normotensive men }\end{array}$ & $\begin{array}{l}\text { Trp64Arg polymorphism was related to BP elevations, but not to } \\
\text { weight gain in originally nonobese subjects. }\end{array}$ \\
\hline $\begin{array}{l}\text { Kawaguchi et al. } \\
\text { [29] }\end{array}$ & 2006 & Japanese & $\begin{array}{l}55 \text { overweight/obese } \\
\text { men }\end{array}$ & $\begin{array}{l}\text { Trp64Arg polymorphism was related to further weight gain in } \\
\text { originally obese subjects. }\end{array}$ \\
\hline Gjesing et al. [63] & 2007 & $\begin{array}{l}\text { Danish- } \\
\text { Caucasians }\end{array}$ & 7,605 & $\begin{array}{l}\text { Trp64Arg polymorphism did not confer an increased risk of } \\
\text { obesity among Danes, although the variant is associated with type } \\
2 \text { diabetes and quantitative traits related to type } 2 \text { diabetes. }\end{array}$ \\
\hline
\end{tabular}

TABLE 4: Confounding variables considered to cause the discrepancy of the relationships between $\beta$-adrenoceptor polymorphisms and phenotypes of obesity, hypertension, and diabetes.

\begin{tabular}{ll}
\hline Variables [reference number] & Findings in the studies \\
\hline Severity of obesity $[23,28,29]$ & $\begin{array}{l}\text { In lean subjects, } \beta 2 \text {-AR polymorphisms linked to obesity and obesity-related hypertension, but in } \\
\text { obese subjects } \beta 2 \text { - and } \beta 3 \text {-AR Polymorphisms related to obesity and obesity-related hypertension. } \\
\text { Morbid obesity was linked with } \beta 3 \text {-AR polymorphisms, but Overweight or mild obesity was not } \\
\text { associated with those. }\end{array}$ \\
Interaction between $\beta 1$ - and $\beta 2$-AR polymorphisms with changes in BMI was observed in men \\
only, while in women an interaction between $\beta 1$ - and $\beta 3$-AR polymorphisms was observed in a \\
longitudinal over a 24 -year period large cohort study.
\end{tabular}

AR: adrenoceptor; BMI: body mass index.

in combination with a smaller increase in $\beta 1$-adrenoceptor function [91]. Recently, Eriksson et al. [76] observed that Trp64Arg polymorphism in the $\beta 3$-receptor, which associates with obesity, is accompanied by changes in lipolytic sensitivity of the receptor in human adipocytes. Many epidemiological studies have shown the strong relationships between $\beta 3$ adrenoceptor polymorphisms (mainly Trp54Arg), obesity, metabolic syndrome, and hypertension [87-92] (Table 3).
3.4. Confounding Variables Affecting the Relationships of $\beta$ Adrenoceptor Polymorphisms with Obesity, Hypertension and Diabetes (Table 4). Tables 1-3 show the discordant contributions of $\beta$-adrenoceptor polymorphisms to obesity. Table 4 summarizes factors which might explain the discrepancy of published data. Importantly, haplotypes of polymorphisms have strong influence on $\beta$-adrenoceptor function in each polymorphism $[25,73,86,93-97]$. 


\section{Sympathetic Nervous System Activity and $\beta 2$ - and $\beta 3$-Adrenoceptor Polymorphisms in Obesity}

Many studies have examined the associations of the $\beta 2$ or $\beta 3$-adrenoceptor polymorphisms with obesity and blood pressure as mentioned above. A series of studies conducted by Masuo et al. have included measurements of sympathetic nervous system activity $[24,26]$. In a longitudinal study over 5 years, originally nonobese, normotensive subjects carrying the Gly16 allele of Arg16Gly, the combination of $\beta 2$-adrenoceptor polymorphisms and high plasma norepinephrine levels on entry were linked to weight gain and blood pressure elevations in addition to weight gaininduced blood pressure elevations [24]. In a weight loss study over a 24-month period, the $\beta 2$-adrenoceptor the Gly16 allele of Arg16Gly was associated with resistance to long term significant weight loss, and the Glu27 allele was linked to resistance to short-term weight loss [26]. Nonobese normotensive men carrying the Gly16 allele of Arg16Gly had a higher frequency of insulin resistance, as indicated by elevation in the homeostasis model assessment for insulin resistance (HOMA) index. This deterioration in insulin resistance is generally observed in obesity and hypertension $[27,36,44,98]$. These studies provide strong evidence for the linkage between $\beta 2$-adrenoceptor polymorphisms, heightened sympathetic nervous system activity, obesity, hypertension, and the development of insulin resistance.

\section{Elevated Sympathetic Nervous Activity in Obesity Is a Risk Factor for Cardiovascular Complications and Renal Complications}

The increased risk of cardiovascular complications in obesity, especially associated with hypertension or type 2 diabetes, has been attributed to a variety of mechanisms, including dyslipidemia, coagulation abnormalities, endothelial dysfunction, chronic sympathetic nerve activation, and repeated occurrence of excessive hyperinsulinemia [99-102]. Sympathetic nerve hyperactivity leads to arterial blood pressure elevation [103-105], triggers arterial damage, and results in cardiovascular events. Recent studies and reviews reported that sympathetic nerve stimulation contributes to the progression of renal disease $[106,107]$. Norepinephrine infusion into the renal artery in dogs produced a reversible ischemic model of acute renal failure [108]. Another study demonstrated renal protection by $\beta$-adrenergic receptor blockade in a nephrectomized rat without any BP changes [109]. Plasma norepinephrine and heightened sympathetic nerve activity may predict mortality and incident cardiovascular events including renal injury in large cohort longitudinal studies [110] and clinical studies [111, 112]. Renal injury also predicts the development of cardiovascular disease $[105,106,110,111]$. There is consistent evidence that elevated sympathetic nervous activity predicts mortality in cardiovascular disease such as in patients with heart failure [111] and end-stage renal disease [112, 113]. Given these observations and the recent demonstration of the effectiveness of catheter based sympathetic renal denervation for the treatment of refractory hypertension [114, 115], it may be of importance to aim antihypertensive treatments or anti-diabetic treatment not only at the reduction of raised blood pressure or blood glucose but also at the excessive sympathetic activation that may underpin these effects.

\section{Conclusions}

Established and emerging data emphasises the importance of the sympathetic nervous system in obesity and obesity-related illness. Sympathetic nervous system activity and $\beta$-adrenoceptor polymorphisms (mainly $\beta 2$ - and $\beta 3$ adrenoceptor polymorphisms) may contribute to the onset and maintenance of obesity; however, the findings have been discordant. A better understanding of the pathogenesis of obesity, including an understanding of adrenoceptor polymorphisms and their impact on sympathetic nervous activity might help in the prevention of obesity and the pharmacological treatment of obesity-related illness including hypertension and insulin resistance.

\section{Disclosure}

The laboratory of Dr. Lambert GW currently receives research funding from private organisations including ARDIAN Inc, Allergan, Abbott (formerly Solvay) Pharmaceuticals, and Scientific Intake. These organizations played no role in this paper. The investigators report no conflict of interests with regards to this paper.

\section{References}

[1] A. H. Mokdad, B. A. Bowman, E. S. Ford, F. Vinicor, J. S. Marks, and J. P. Koplan, "The continuing epidemics of obesity and diabetes in the United States," The Journal of the American Medical Association, vol. 286, no. 10, pp. 11951200, 2001.

[2] C. Heidemann, H. Boeing, T. Pischon, U. Nöthlings, H. G. Joost, and M. B. Schulze, "Association of a diabetes risk score with risk of myocardial infarction, stroke, specific types of cancer, and mortality: a prospective study in the European Prospective Investigation into Cancer and Nutrition (EPIC)Potsdam cohort," European Journal of Epidemiology, vol. 24, no. 6, pp. 281-288, 2009.

[3] K. M. Flegal, B. I. Graubard, D. F. Williamson, and M. H. Gail, "Cause-specific excess deaths associated with underweight, overweight, and obesity," The Journal of the American Medical Association, vol. 298, no. 17, pp. 2028-2037, 2007.

[4] E. Lambert, C. I. Sari, T. Dawood et al., "Sympathetic nervous system activity is associated with obesity-induced subclinical organ damage in young adults," Hypertension, vol. 56, no. 3, pp. 351-358, 2010.

[5] F. Ramsey, A. Ussery-Hall, D. Garcia et al., "Prevalence of selected risk behaviors and chronic diseases: behavioral Risk Factor Surveillance System (BRFSS), 39 steps communities, United States, 2005," Morbidity and Mortality Weekly Report. Surveillance Summaries/CDC, vol. 57, no. 11, pp. 1-20, 2008. 
[6] C. L. Ogden, C. D. Fryar, M. D. Carroll, and K. M. Flegal, "Mean body weight, height, and body mass index, United States 1960-2002," Advance Data, no. 347, pp. 1-17, 2004.

[7] A. H. Mokdad, M. K. Serdula, W. H. Dietz, B. A. Bowman, J. S. Marks, and J. P. Koplan, "The spread of the obesity epidemic in the United States, 1991-1998," The Journal of the American Medical Association, vol. 282, no. 16, pp. 15191522, 1999.

[8] G. W. Lambert, N. E. Straznicky, E. A. Lambert, J. B. Dixon, and M. P. Schlaich, "Sympathetic nervous activation in obesity and the metabolic syndrome-causes, consequences and therapeutic implications," Pharmacology and Therapeutics, vol. 126, no. 2, pp. 159-172, 2010.

[9] S. R. Preis, S. J. Hwang, S. Coady et al., "Trends in all-cause and cardiovascular disease mortality among women and men with and without diabetes mellitus in the framingham heart study, 1950 to 2005," Circulation, vol. 119, no. 13, pp. 17281735, 2009.

[10] N. E. Straznicky, G. W. Lambert, K. Masuo et al., "Blunted sympathetic neural response to oral glucose in obese subjects with the insulin-resistant metabolic syndrome," American Journal of Clinical Nutrition, vol. 89, no. 1, pp. 27-36, 2009.

[11] K. Masuo, H. Mikami, T. Ogihara, and M. L. Tuck, "Differences in insulin and sympathetic responses to glucose ingestion due to family history of hypertension," American Journal of Hypertension, vol. 9, no. 8, pp. 739-745, 1996.

[12] M. Spraul, E. Ravussin, A. M. Fontvieille, R. Rising, D. E. Larson, and E. A. Anderson, "Reduced sympathetic nervous activity. A potential mechanism predisposing to body weight gain,” Journal of Clinical Investigation, vol. 92, no. 4, pp. 1730-1735, 1993.

[13] A. M. Cypess, S. Lehman, G. Williams et al., "Identification and importance of brown adipose tissue in adult humans," The New England Journal of Medicine, vol. 360, no. 15, pp. 1509-1517, 2009.

[14] J. A. Timmons and B. K. Pedersen, "The importance of brown adipose tissue," The New England Journal of Medicine, vol. 361, no. 4, pp. 415-416, 2009.

[15] H. S. Sacks, "The importance of brown adipose tissue," The New England Journal of Medicine, vol. 361, no. 4, p. 418, 2009.

[16] S. Iwashita, M. Tanida, N. Terui et al., "Direct measurement of renal sympathetic nervous activity in high-fat diet-related hypertensive rats," Life Sciences, vol. 71, no. 5, pp. 537-546, 2002.

[17] M. B. Monroe, D. R. Seals, L. F. Shapiro, C. Bell, D. Johnson, and P. Parker-Jones, "Direct evidence for tonic sympathetic support of resting metabolic rate in healthy adult humans," American Journal of Physiology, vol. 280, no. 5, pp. E740E744, 2001.

[18] E. E. Blaak, M. A. van Baak, K. P. G. Kempen, and W. H. M. Saris, "Role of $\alpha$ - and $\beta$-adrenoceptors in sympathetically mediated thermogenesis," American Journal of Physiology, vol. 264, no. 1, part 1, pp. E11-E17, 1993.

[19] E. Hagström-Toft, S. Enoksson, E. Moberg, J. Bolinder, and P. Arner, " $\beta$-adrenergic regulation of lipolysis and blood flow in human skeletal muscle in vivo," American Journal of Physiology, vol. 275, no. 6, pp. E909-E916, 1998.

[20] S. Enoksson, M. Talbot, F. Rife, W. V. Tamborlane, R. S. Sherwin, and S. Caprio, "Impaired in vivo stimulation of lipolysis in adipose tissue by selective $\beta 2$-adrenergic agonist in obese adolescent girls," Diabetes, vol. 49, no. 12, pp. 2149 2153, 2000.
[21] K. Masuo, H. Mikami, T. Ogihara, and M. L. Tuck, "Familial hypertension, insulin, sympathetic activity, and blood pressure elevation," Hypertension, vol. 32, no. 1, pp. 96-100, 1998.

[22] K. Masuo, H. Mikami, T. Ogihara, and M. L. Tuck, "Familial obesity, sympathetic activation and blood pressure level," Blood Pressure, vol. 10, no. 4, pp. 199-204, 2001.

[23] J. Cui, J. L. Hopper, and S. B. Harrap, "Genes and family environment explain correlations between blood pressure and body mass index," Hypertension, vol. 40, no. 1, pp. 7-12, 2002.

[24] K. Masuo, T. Katsuya, Y. Fu, H. Rakugi, T. Ogihara, and M. L. Tuck, “ $\beta 2$ - and $\beta 3$-adrenergic receptor polymorphisms are related to the onset of weight gain and blood pressure elevation over 5 years," Circulation, vol. 111, no. 25, pp. 34293434, 2005.

[25] A. C. Pereira, M. S. Floriano, G. F. A. Mota et al., " $\beta 2$ adrenoceptor functional gene variants, obesity, and blood pressure level interactions in the general population," Hypertension, vol. 42, no. 4, pp. 685-692, 2003.

[26] K. Masuo, T. Katsuya, H. Kawaguchi et al., "Rebound weight gain as associated with high plasma norepinephrine levels that are mediated through polymorphisms in the $\beta 2$ adrenoceptor," American Journal of Hypertension, vol. 18, no. 11, pp. 1508-1516, 2005.

[27] K. Masuo, T. Katsuya, Y. Fu, H. Rakugi, T. Ogihara, and M. L. Tuck, " $\beta 2$-adrenoceptor polymorphisms relate to insulin resistance and sympathetic overactivity as early markers of metabolic disease in nonobese, normotensive individuals," American Journal of Hypertension, vol. 18, no. 7, pp. 10091014, 2005.

[28] K. Masuo, T. Katsuya, H. Kawaguchi et al., “ $\beta 2$-adrenoceptor polymorphisms relate to obesity through blunted leptinmediated sympathetic activation," American Journal of Hypertension, vol. 19, no. 10, pp. 1084-1091, 2006.

[29] H. Kawaguchi, K. Masuo, T. Katsuya et al., " $\beta 2$ - and $\beta 3$ adrenoceptor polymorphisms relate to subsequent weight gain and blood pressure elevation in obese normotensive individuals," Hypertension Research, vol. 29, no. 12, pp. 951959, 2006.

[30] T. J. Maxwell, M. M. Ameyaw, S. Pritchard et al., "Beta-2 adrenergic receptor genotypes and haplotypes in different ethnic groups," International Journal of Molecular Medicine, vol. 16, no. 4, pp. 573-580, 2005.

[31] N. E. Straznicky, N. Eikelis, E. A. Lambert, and M. D. Esler, "Mediators of sympathetic activation in metabolic syndrome obesity," Current Hypertension Reports, vol. 10, no. 6, pp. 440447, 2008.

[32] J. L. González Sánchez, A. M. Proenza, M. T. Martínez Larrad et al., "The glutamine 27 glutamic acid polymorphism of the $\beta 2$-adrenoceptor gene is associated with abdominal obesity and greater risk of impaired glucose tolerance in men but not in women: a population-based study in Spain," Clinical Endocrinology, vol. 59, no. 4, pp. 476-481, 2003.

[33] N. E. Straznicky, E. A. Lambert, G. W. Lambert, K. Masuo, M. D. Esler, and P. J. Nestel, "Effects of dietary weight loss on sympathetic activity and cardiac risk factors associated with the metabolic syndrome," Journal of Clinical Endocrinology \& Metabolism, vol. 90, no. 11, pp. 5998-6005, 2005.

[34] L. Landsberg, "Insulin-mediated sympathetic stimulation: role in the pathogenesis of obesity-related hypertension (or, how insulin affects blood pressure, and why)," Journal of Hypertension, vol. 19, no. 3, pp. 523-528, 2001. 
[35] E. A. Anderson, R. P. Hoffman, T. W. Balon, C. A. Sinkey, and A. L. Mark, "Hyperinsulinemia produces both sympathetic neural activation and vasodilation in normal humans," Journal of Clinical Investigation, vol. 87, no. 6, pp. 2246-2252, 1991.

[36] E. Ferrannini, "Physiological and metabolic consequences of obesity," Metabolism, vol. 44, no. 9, supplement 3, pp. 15-17, 1995.

[37] J.-P. Montani, V. Antic, Z. Yang, and A. Dulloo, "Pathways from obesity to hypertension: from the perspective of a vicious triangle," International Journal of Obesity, vol. 26, supplement 2, pp. S28-S38, 2002.

[38] C. L. Gentile, J. S. Orr, B. M. Davy, and K. P. Davy, "Modest weight gain is associated with sympathetic neural activation in nonobese humans," American Journal of Physiology, vol. 292, no. 5, pp. R1834-R1838, 2007.

[39] M. J. Barnes, K. Lapanowski, A. Conley, J. A. Rafols, K. L. C. Jen, and J. C. Dunbar, "High fat feeding is associated with increased blood pressure, sympathetic nerve activity and hypothalamic mu opioid receptors," Brain Research Bulletin, vol. 61, no. 5, pp. 511-519, 2003.

[40] K. Masuo, H. Mikami, T. Ogihara, and M. L. Tuck, "Weight reduction and pharmacologic treatment in obese hypertensives," American Journal of Hypertension, vol. 14, no. 6, part 1, pp. 530-538, 2001.

[41] B. Andersson, M. Elam, B. G. Wallin, P. Bjorntorp, and O. K. Andersson, "Effect of energy-restricted diet on sympathetic muscle nerve activity in obese women," Hypertension, vol. 18, no. 6, pp. 783-789, 1991.

[42] N. E. Straznicky, E. A. Lambert, G. W. Lambert, K. Masuo, M. D. Esler, and P. J. Nestel, "Effects of dietary weight loss on sympathetic activity and cardiac risk factors associated with the metabolic syndrome," Journal of Clinical Endocrinology \& Metabolism, vol. 90, no. 11, pp. 5998-6005, 2005.

[43] K. Masuo, H. Mikami, T. Ogihara, and M. L. Tuck, "Differences in mechanisms between weight loss-sensitive and -resistant blood pressure reduction in obese subjects," Hypertension Research, vol. 24, no. 4, pp. 371-376, 2001.

[44] M. L. Tuck, J. R. Sowers, and L. Dornfeld, "Reductions in plasma catecholamines and blood pressure during weight loss in obese subjects," Acta Endocrinologica, vol. 102, no. 2, pp. 252-257, 1983.

[45] G. Grassi, G. Seravalle, M. Colombo et al., "Body weight reduction, sympathetic nerve traffic, and arterial baroreflex in obese normotensive humans," Circulation, vol. 97, no. 20, pp. 2037-2042, 1998.

[46] L. Landsberg, "Diet, obesity and hypertension: an hypothesis involving insulin, the sympathetic nervous system, and adaptive thermogenesis," The Quarterly Journal of Medicine, vol. 61, no. 236, pp. 1081-1090, 1986.

[47] L. Landsberg and J. B. Young, "Diet and the sympathetic nervous system: relationship to hypertension," International Journal of Obesity, vol. 5, supplement 1, pp. 79-91, 1981.

[48] L. Landsberg and D. R. Krieger, "Obesity, metabolism, and the sympathetic nervous system," American Journal of Hypertension, vol. 2, no. 3, pp. 125S-132S, 1989.

[49] S. Julius, M. Valentini, and P. Palatini, "Overweight and hypertension: a 2-way street?” Hypertension, vol. 35 , no. 3 , pp. 807-813, 2000.

[50] K. O'Dea, M. Esler, and P. Leonard, "Noradrenaline turnover during under- and over-eating in normal weight subjects," Metabolism, vol. 31, no. 9, pp. 896-899, 1982.
[51] K. Masuo, H. Kawaguchi, H. Mikami, T. Ogihara, and M. L. Tuck, "Serum uric acid and plasma norepinephrine concentrations predict subsequent weight gain and blood pressure elevation," Hypertension, vol. 42, no. 4, pp. 474-480, 2003.

[52] K. Masuo, H. Mikami, T. Ogihara, and M. L. Tuck, "Weight gain-induced blood pressure elevation," Hypertension, vol. 35, no. 5, pp. 1135-1140, 2000.

[53] M. Valentini, S. Julius, P. Palatini et al., "Attenuation of haemodynamic, metabolic and energy expenditure responses to isoproterenol in patients with hypertension," Journal of Hypertension, vol. 22, no. 10, pp. 1999-2006, 2004.

[54] Y. T. Yang and M. A. McElligott, "Multiple actions of $\beta$-adrenergic agonists on skeletal muscle and adipose tissue," Biochemical Journal, vol. 261, no. 1, pp. 1-10, 1989.

[55] V. Large, L. Hellstrom, S. Reynisdottir et al., "Human beta-2 adrenoceptor gene polymorphisms are highly frequent in obesity and associate with altered adipocyte beta-2 adrenoceptor function," Journal of Clinical Investigation, vol. 100, no. 12, pp. 3005-3013, 1997.

[56] O. Ukkola, A. Tremblay, and C. Bouchard, "Beta-2 adrenergic receptor variants are associated with subcutaneous fat accumulation in response to long-term overfeeding," International Journal of Obesity, vol. 25, no. 11, pp. 1604-1608, 2001.

[57] S. Enoksson, E. Hagström-Toft, J. Nordahl et al., "Marked reutilization of free fatty acids during activated lipolysis in human skeletal muscle," Journal of Clinical Endocrinology \& Metabolism, vol. 90, no. 2, pp. 1189-1195, 2005.

[58] S. M. Echwald, T. I. A. Sørensen, A. Tybjærg-Hansen, T. Andersen, and O. Pedersen, "Gln27Glu variant of the human $\beta 2$-adrenoreceptor gene is not associated with early-onset obesity in Danish men," Diabetes, vol. 47, no. 10, pp. 1657-1658, 1998.

[59] L. Hellström, V. Large, S. Reynisdottir, H. Wahrenberg, and P. Arner, "The different effects of a Gln27Glu $\beta 2$-adrenoceptor gene polymorphism on obesity in males and in females," Journal of Internal Medicine, vol. 245, no. 3, pp. 253-259, 1999.

[60] I. J. Dionne, M. J. Garant, A. A. Nolan et al., "Association between obesity and a polymorphism in the $\beta_{1}$-adrenoceptor gene (Gly389Arg ADRB1) in Caucasian women," International Journal of Obesity, vol. 26, no. 5, pp. 633-639, 2002.

[61] J. Tafel, I. Branscheid, B. Skwarna et al., "Variants in the human $\beta 1-, \beta 2$ - and $\beta 3$-adrenergic receptor genes are not associated with morbid obesity in children and adolescents," Diabetes, Obesity \& Metabolism, vol. 6, no. 6, pp. 452-455, 2004.

[62] Y. Linné, I. Dahlman, and J. Hoffstedt, “ $\beta 1$-adrenoceptor gene polymorphism predicts long-term changes in body weight," International Journal of Obesity, vol. 29, no. 5, pp. 458-462, 2005.

[63] A. P. Gjesing, G. Andersen, A. Albrechtsen et al., "Studies of associations between the Arg389Gly polymorphism of the $\beta 1$-adrenergic receptor gene (ADRB1) and hypertension and obesity in 7677 Danish white subjects," Diabetic Medicine, vol. 24, no. 4, pp. 392-397, 2007.

[64] S. Nonen, I. Yamamoto, J. Liu et al., "Adrenergic $\beta 1$ receptor polymorphism (Ser49gly) is associated with obesity in type II diabetic patients," Biological \& Pharmaceutical Bulletin, vol. 31, no. 2, pp. 295-298, 2008.

[65] M. Rasmussen, A. Belza, T. Almdal et al., "Change in $\beta 1-$ adrenergic receptor protein concentration in adipose tissue correlates with diet-induced weight loss," Clinical Science, vol. 108, no. 4, pp. 323-329, 2005. 
[66] M. Ryden, J. Hoffstedt, P. Eriksson, S. Bringman, and P. Arner, "The Arg389Gly $\beta 1$-adrenergic receptor gene polymorphism and human fat cell lipolysis," International Journal of Obesity, vol. 25, no. 11, pp. 1599-1603, 2001.

[67] K. Bengtsson, O. Melander, M. Orho-Melander et al., "Polymorphism in the $\beta_{1}$-adrenergic receptor gene and hypertension," Circulation, vol. 104, no. 2, pp. 187-190, 2001.

[68] L. M. Humma, B. J. Puckett, H. E. Richardson et al., "Effects of beta-adrenoceptor genetic polymorphisms on resting hemodynamics in patients undergoing diagnostic testing for ischemia," American Journal of Cardiology, vol. 88, no. 9, pp. 1034-1037, 2001.

[69] B. Kortner, A. Wolf, D. Wendt, U. Beisiegel, and D. Evans, "Lack of association between a human $\beta$-2 adrenoceptor gene polymorphism (gln27glu) and morbid obesity," International Journal of Obesity, vol. 23, no. 10, pp. 1099-1100, 1999.

[70] N. R. Stob, D. R. Seals, J. Jensen et al., "Increased thermogenic responsiveness to intravenous $\beta$-adrenergic stimulation in habitually exercising humans is not related to skeletal muscle $\beta 2$-adrenergic receptor density," Experimental Physiology, vol. 92, no. 5, pp. 823-830, 2007.

[71] A. Meirhaeghe, N. Helbecque, D. Cottel, and P. Amouyel, "Impact of polymorphisms of the human $\beta 2$-adrenoceptor gene on obesity in a French population," International Journal of Obesity, vol. 24, no. 3, pp. 382-387, 2000.

[72] K. Bengtsson, M. Orho-Melander, O. Melander et al., " $\beta 2$-adrenergic receptor gene variation and hypertension in subjects with type 2 diabetes," Hypertension, vol. 37, no. 5, pp. 1303-1308, 2001.

[73] H. Jiao, I. Dahlman, P. Eriksson, J. Kere, and P. Arner, "A common $\beta 2$-adrenoceptor gene haplotype protects against obesity in Swedish women," Obesity Research, vol. 13, no. 10, pp. 1645-1650, 2005.

[74] A. Petrone, S. Zavarella, G. Iacobellis et al., "Association of $\beta 2$ adrenergic receptor polymorphisms and related haplotypes with triglyceride and LDL-cholesterol levels," European Journal of Human Genetics, vol. 14, no. 1, pp. 94-100, 2006.

[75] A. P. Gjesing, T. Sparsø, K. Borch-Johnsen et al., "No consistent effect of ADRB2 haplotypes on obesity, hypertension and quantitative traits of body fatness and blood pressure among 6,514 adult danes," PLoS One, vol. 4, no. 9, Article ID e7206, 2009.

[76] P. Eriksson, I. Dahlman, M. Ryden, J. Hoffstedt, and P. Arner, "Relationship between $\beta$-2 adrenoceptor gene haplotypes and adipocyte lipolysis in women," International Journal of Obesity, vol. 28, no. 2, pp. 185-190, 2004.

[77] S. A. Green, J. Turki, M. Innis, and S. B. Liggett, "Aminoterminal polymorphisms of the human $\beta 2$-adrenergic receptor impart distinct agonist-promoted regulatory properties," Biochemistry, vol. 33, no. 32, pp. 9414-9419, 1994.

[78] V. Dishy, G. G. Sofowora, H.-G. Xie et al., "The effect of common polymorphisms of the $\beta 2$-adrenergic receptor on agonist-mediated vascular desensitization," The New England Journal of Medicine, vol. 345, no. 14, pp. 1030-1035, 2001.

[79] G. Gratze, J. Fortin, R. Labugger et al., “ $\beta-2$ adrenergic receptor variants affect resting blood pressure and agonist-induced vasodilation in young adult Caucasians," Hypertension, vol. 33, no. 6, pp. 1425-1430, 1999.

[80] B. D. Hoit, D. P. Suresh, L. Craft, R. A. Walsh, and S. B. Liggett, " $\beta 2$-adrenergic receptor polymorphisms at amino acid 16 differentially influence agonist-stimulated blood pressure and peripheral blood flow in normal individuals," American Heart Journal, vol. 139, no. 3, pp. 537-542, 2000.
[81] K. Leineweber, "Beta-adrenergic receptor polymorphism in human cardiovascular disease," Annals of Medicine, vol. 36, supplement 1, pp. 64-69, 2004.

[82] C. Bell, N. R. Stob, and D. R. Seals, "Thermogenic responsiveness to nonspecific $\beta$-adrenergic stimulation is not related to genetic variation in codon 16 of the $\beta 2$-adrenergic receptor," American Journal of Physiology, vol. 290, no. 4, pp. E703-E707, 2006.

[83] K. Clement, C. Vaisse, B. S. J. Manning et al., "Genetic variation in the $\beta 3$-adrenergic receptor and an increased capacity to gain weight in patients with morbid obesity," The New England Journal of Medicine, vol. 333, no. 6, pp. 352-354, 1995.

[84] N. Sakane, T. Yoshida, T. Umekawa, A. Kogure, Y. Takakura, and M. Kondo, "Effects of Trp64Arg mutation in the $\beta 3$-adrenergic receptor gene on weight loss, body fat distribution, glycemic control, and insulin resistance in obese type 2 diabetic patients," Diabetes Care, vol. 20, no. 12, pp. 1887-1890, 1997.

[85] T. Umekawa, T. Yoshida, N. Sakane, A. Kogure, M. Kondo, and H. Honjyo, "Trp64Arg mutation of $\beta 3$-adrenoceptor gene deteriorates lipolysis induced by $\beta 3$-adrenoceptor agonist in human omental adipocytes," Diabetes, vol. 48, no. 1, pp. 117-120, 1999.

[86] K. Endo, H. Yanagi, C. Hirano, H. Hamaguchi, S. Tsuchiya, and S. Tomura, "Association of Trp64Arg polymorphism of the $\beta 3$-adrenergic receptor gene and no association of Gln223Arg polymorphism of the leptin receptor gene in Japanese schoolchildren with obesity," International Journal of Obesity, vol. 24, no. 4, pp. 443-449, 2000.

[87] T. Oizumi, M. Daimon, T. Saitoh et al., "Genotype Arg/Arg, but not Trp/Arg, of the Trp64Arg polymorphism of the $\beta_{3}$-adrenergic receptor is associated with type 2 diabetes and obesity in a large Japanese sample," Diabetes Care, vol. 24, no. 9, pp. 1579-1583, 2001.

[88] A. P. Gjesing, G. Andersen, K. S. Burgdorf et al., "Studies of the associations between functional $\beta_{2}$-adrenergic receptor variants and obesity, hypertension and type 2 diabetes in 7,808 white subjects," Diabetologia, vol. 50, no. 3, pp. 563-568, 2007.

[89] N. Kurokawa, K. Nakai, S. Kameo, Z. M. Liu, and H. Satoh, "Association of BMI with the $\beta 3$-adrenergic receptor gene polymorphism in Japanese: meta-analysis," Obesity Research, vol. 9, no. 12, pp. 741-745, 2001.

[90] P. Arner, "The $\beta 3$-adrenergic receptor-a cause and cure of obesity?" The New England Journal of Medicine, vol. 333, no. 6, pp. 382-383, 1995.

[91] J. Hoffstedt, O. Poirier, A. Thörne et al., "Polymorphism of the human $\beta 3$-adrenoceptor gene forms a well-conserved haplotype that is associated with moderate obesity and altered receptor function," Diabetes, vol. 48, no. 1, pp. 203-205, 1999.

[92] J. Walston, K. Silver, C. Bogardus et al., "Time of onset of non-insulin-dependent diabetes mellitus and genetic variation in the $\beta 3$-adrenergic-receptor gene," The New England Journal of Medicine, vol. 333, no. 6, pp. 343-347, 1995.

[93] D. L. Ellsworth, S. A. Coady, W. Chen, S. R. Srinivasan, E. Boerwinkle, and G. S. Berenson, "Interactive effects between polymorphisms in the $\beta$-adrenergic receptors and longitudinal changes in obesity," Obesity Research, vol. 13, no. 3, pp. 519-526, 2005. 
[94] I. C. Trombetta, L. T. Batalha, M. U. P. B. Rondon et al., "Gly16+Glu27 $\beta 2$-adrenoceptor polymorphisms cause increased forearm blood flow responses to mental stress and handgrip in humans," Journal of Applied Physiology, vol. 98, no. 3, pp. 787-794, 2005.

[95] A. Sandilands, G. Yeo, M. J. Brown, and K. M. O'Shaughnessy, "Functional responses of human $\beta 1$ adrenoceptors with defined haplotypes for the common $389 \mathrm{R}>\mathrm{G}$ and $49 \mathrm{~S}>$ G polymorphisms," Pharmacogenetics, vol. 14, no. 6, pp. 343-349, 2004.

[96] M. Tomaszewski, N. J. R. Brain, F. J. Charchar et al., "Essential hypertension and $\beta 2$-adrenergic receptor gene: linkage and association analysis," Hypertension, vol. 40, no. 3, pp. 286-291, 2002.

[97] S. M. Herrmann, V. Nicaud, L. Tiret et al., "Polymorphisms of the $\beta 2$-adrenoceptor (ADRB2) gene and essential hypertension: the ECTIM and PEGASE studies," Journal of Hypertension, vol. 20, no. 2, pp. 229-235, 2002.

[98] K. Masuo, H. Mikami, T. Ogihara, and M. L. Tuck, "Sympathetic nerve hyperactivity precedes hyperinsulinemia and blood pressure elevation in a young, nonobese Japanese population," American Journal of Hypertension, vol. 10, no. 1, pp. 77-83, 1997.

[99] W. B. Kannel and D. L. McGee, "Diabetes and cardiovascular disease. The Framingham study," The Journal of the American Medical Association, vol. 241, no. 19, pp. 2035-2038, 1979.

[100] V. Frighi, I. Stratton, R. Holman, D. Matthews, A. Neil, and R. Turner, "Hypertension in Diabetes Study (HDS): II. Increased risk of cardiovascular complications in hypertensive type 2 diabetic patients," Journal of Hypertension, vol. 11, no. 3, pp. 319-325, 1993.

[101] G. J. J. Tack, P. Smits, J. J. Willemsen, J. W. M. Lenders, T. Thien, and J. A. Lutterman, "Effects of insulin on vascular tone and sympathetic nervous system in NIDDM," Diabetes, vol. 45, no. 1, pp. 15-22, 1996.

[102] K. Masuo, H. Rakugi, T. Ogihara, M. D. Esler, and G. W. Lambert, "Cardiovascular and renal complications of type 2 diabetes in obesity: role of sympathetic nerve activity and insulin resistance," Current Diabetes Reviews, vol. 6, no. 2, pp. 58-67, 2010.

[103] S. Julius and S. Nesbitt, "Sympathetic overactivity in hypertension a moving target," American Journal of Hypertension, vol. 9, no. 11, pp. 113s-120s, 1996.

[104] G. Mancia, G. Grassi, C. Giannattasio, and G. Seravalle, "Sympathetic activation in the pathogenesis of hypertension and progression of organ damage," Hypertension, vol. 34, no. 4, part 2, pp. 724-728, 1999.

[105] M. Esler, G. Jennings, and G. Lambert, "Noradrenaline release and the pathophysiology of primary human hypertension," American Journal of Hypertension, vol. 2, no. 3, part 2, pp. 140S-146S, 1989.

[106] J. A. Joles and H. A. Koomans, "Causes and consequences of increased sympathetic activity in renal disease," Hypertension, vol. 43, no. 4, pp. 699-706, 2004.

[107] M. P. Schlaich, F. Socratous, S. Hennebry et al., "Sympathetic activation in chronic renal failure," Journal of the American Society of Nephrology, vol. 20, no. 5, pp. 933-939, 2009.

[108] R. E. Bulger, T. J. Burke, and R. E. Cronin, "Morphology of norepinephrine-induced acute renal failure in the dog," Anatomical Record, vol. 214, no. 4, pp. 341-347, 1986.

[109] K. Amann, A. Koch, J. Hofstetter et al., "Glomerulosclerosis and progression: effect of subantihypertensive doses of $\alpha$ and $\beta$ blockers," Kidney International, vol. 60 , no. 4, pp. 1309-1323, 2001.
[110] C. Zoccali, F. Mallamaci, S. Parlongo et al., "Plasma norepinephrine predicts survival and incident cardiovascular events in patients with end-stage renal disease," Circulation, vol. 105, no. 11, pp. 1354-1359, 2002.

[111] M. Petersson, P. Friberg, G. Eisenhofer, G. Lambert, and B. Rundqvist, "Long-term outcome in relation to renal sympathetic activity in patients with chronic heart failure," European Heart Journal, vol. 26, no. 9, pp. 906-913, 2005.

[112] K. Masuo, T. Katsuya, K. Sugimoto et al., "High plasma norepinephrine levels associated with $\beta 2$-adrenoceptor polymorphisms predict future renal damage in nonobese normotensive individuals," Hypertension Research, vol. 30, no. 6, pp. 503-511, 2007.

[113] A. Ksiazek and W. Załuska, "Sympathetic overactivity in uremia," Journal of Renal Nutrition, vol. 18, no. 1, pp. 118-121, 2008.

[114] H. Krum, M. Schlaich, R. Whitbourn et al., "Catheter-based renal sympathetic denervation for resistant hypertension: a multicentre safety and proof-of-principle cohort study," The Lancet, vol. 373, no. 9671, pp. 1275-1281, 2009.

[115] M. P. Schlaich, P. A. Sobotka, H. Krum, E. Lambert, and M. D. Esler, "Renal sympathetic-nerve ablation for uncontrolled hypertension," The New England Journal of Medicine, vol. 361, no. 9, pp. 932-934, 2009. 


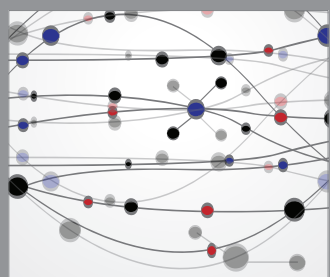

The Scientific World Journal
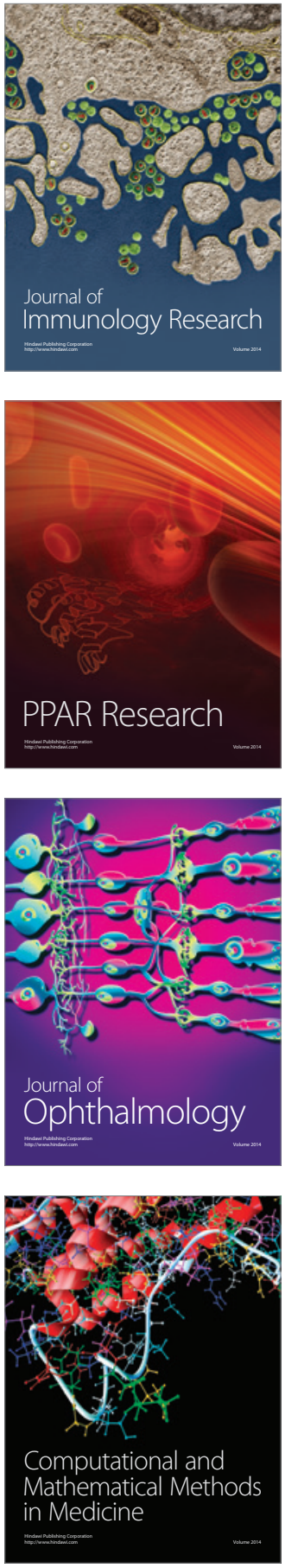

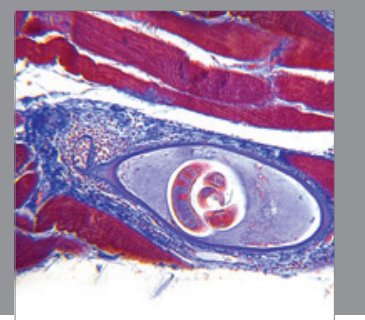

Gastroenterology

Research and Practice
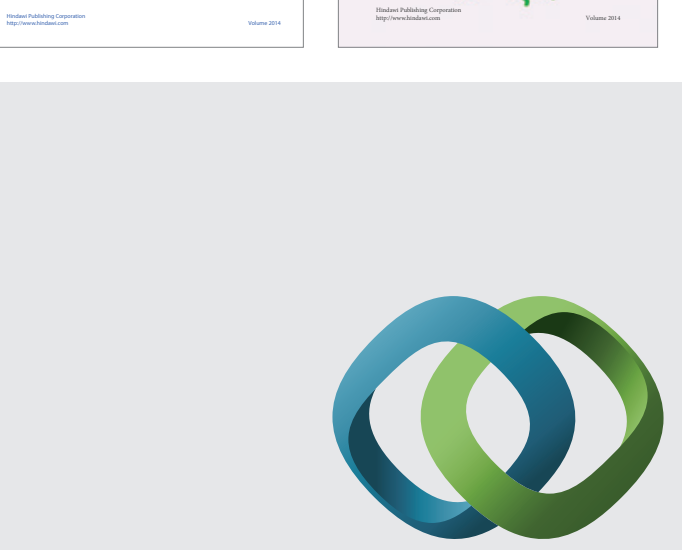

\section{Hindawi}

Submit your manuscripts at

http://www.hindawi.com
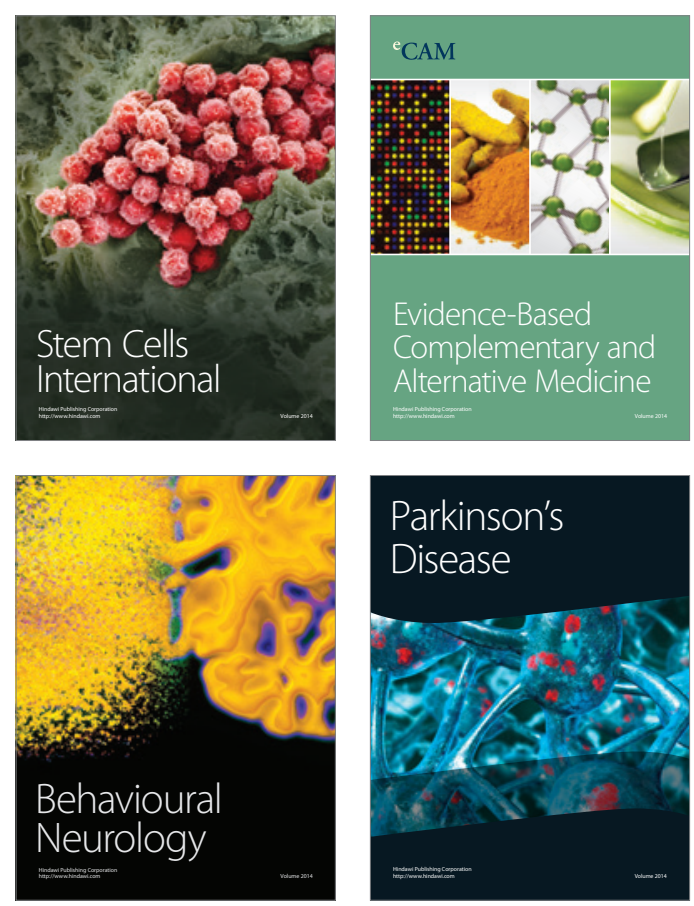

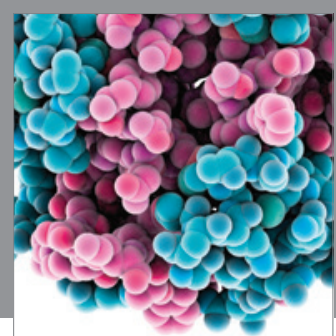

Journal of
Diabetes Research

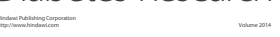

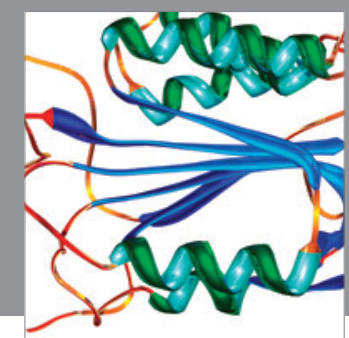

Disease Markers
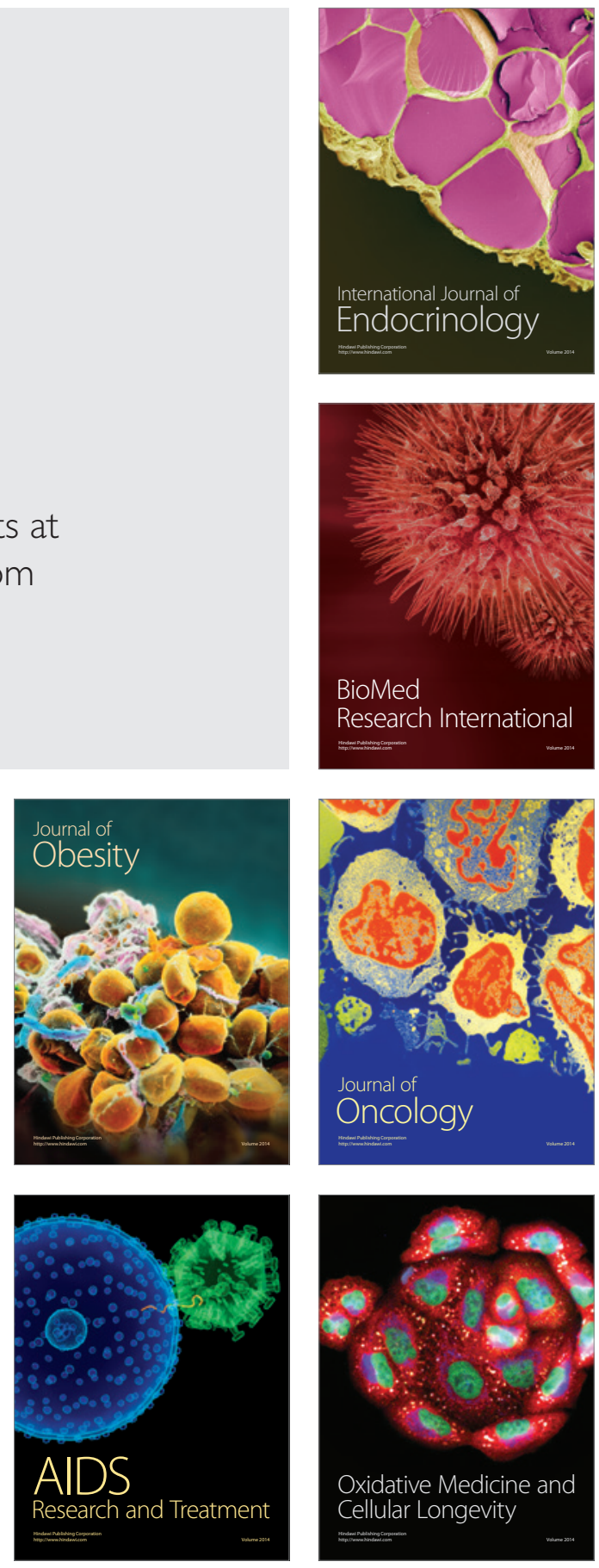